\title{
The Double Transition in Russian Area Studies
}

\author{
R u s s e I I B o v a
}

Dickinson College

\section{Introduction}

Like Russia itself, Russian area studies has been in a state of flux over the past decade. The collapse of communism and the disintegration of the USSR have stimulated a double transition in the field as scholars have had to reconsider both how to define the region and how to study it. Defining the region is a question of demarcating the geographic borders of the field. Now that the common thread of communism has frayed, in what sense do places as diverse as Hungary, Belarus, and Tajikistan, once joined as subjects of study in "Russian and Soviet area studies " programs, continue to constitute an "area?" Once the geographic scope of the area is determined, the question is how to study it. To a large extent, the question facing Russian area studies in this respect is not unlike that confronting area studies programs in general in the era of globalization, as proponents of area studies are challenged by advocates of more comparative and theoretical disciplinary-based approaches which cut across national and cultural boundaries.

At the core of this double transition in Russian area studies is a paradox. While the geographic borders of the area are retreating and the area shrinking, at the same time scholars and students of the region are being stimulated to make connections to other cases and to disciplinary models which take them far beyond the area even as it was once most broadly defined. This simultaneous Balkanization and globalization of Russian area studies is a reflection, more generally, of the real world in the late-20th and early-21st centuries, where we have witnessed simultaneous tendencies toward both localism and globalism on a worldwide 
basis (Barber, 1995; Rosenau, 1990).

The transitions shaping both Russia and Russian area studies clearly carry implications for how to teach our students and prepare them to understand the area. Thus, following a detailed discussion of the double transition in Russian area studies, this essay will consider the pedagogical implications for undergraduate education in Russian studies, in area studies in general, and for study abroad programs in Russia in the early 21 st century.

\section{From the USSR to Russia: How to Define the Region?}

In his controversial article and subsequent book on "the clash of civilizations," Samuel Huntington (1996) identified seven or eight major civilizations in the contemporary world. Elements of at least three of those civilizations were brought together under one political roof in the former USSR. What Huntington referred to as "Slavic-Orthodox" civilization was represented by Ukraine, Belarus, and, of course, Russia itself. "Islamic" civilization could be found in the five Central Asian republics of the Soviet Union (Kazakhstan, Turkmenistan, Uzbekistan, Tajikistan, and Kyrgyzstan) and in the Caucasus region, including both the Soviet Republic of Azerbaijan and parts of southern Russia (e.g., Chechnya). As for "Western" civilization, outposts could be found in the Baltic republics of the USSR (Lithuania, Latvia, and Estonia).

Despite the cultural diversity found across these civilizational divides, the study and treatment of this area as a unit could be intellectually justified. Not only were all of these areas a part of a single state, but it was a highly-centralized state at that. Though a certain amount of cultural diversity was tolerated within the former USSR, political and economic power and authority largely radiated outward from Moscow. In a larger sense the role of Moscow in the former USSR was a reflection of the power of Russia, and the USSR could be seen without much need for stretching historical truth as simply the latest manifestation of a Russian empire which long pre-dated communism in Russia. Thus, "Russian area studies " and "Soviet area studies" could, prior to the 1990s, be viewed as largely interchangeable ways of describing a single intellectual endeavor, and the claim staked by Russian/Soviet area studies to the 
turf of the entire USSR was largely unchallenged from either inside or outside the field.

The geographic reach of "Russian" area studies did not stop at the borders of the former USSR. Much of central and eastern Europe was also a part of the intellectual territory of Russian area studies despite the fact, once again, of considerable cultural diversity both within Eastern Europe and between many parts of East/Central Europe and Russia itself. Like the USSR, Eastern Europe was home to elements of Western, SlavicOrthodox, and Islamic civilization as well as varied national traditions. In many cases, the inhabitants of this region were acutely conscious of these differences among themselves and between themselves and their large Russian neighbor. The famous Czech writer, Milan Kundera, made it very clear that much of Eastern Europe was in essence a part of Western Europe and, by clear implication, an unnatural fit into the Russian area when he wrote:

What does Europe mean to a Hungarian, a Czech, a Pole: For thousands of years their nations have belonged to a part of Europe rooted in Roman Christianity. They have participated in every period of its bistory. For them the word "Europe" does not represent a phenomenon of geography but a spiritual notion synonymous with the West. The moment Hungary is no longer European-that is, no longer Western - it is driven from its destiny, beyond its own history: it loses the essence of its identity. (Kundera 1984: 33)

Kundera's sense of history is further reflected in the insistence of many Czechs, Poles, and Hungarians that they live in Central Europe, not Eastern Europe, and in the reminder that one sometimes receives from central Europeans that Prague is located geographically west of Vienna. Of course, as Kundera emphasizes, the point here is less to give a lesson in geography than a lesson in culture.

Kundera's sense of the cultural affiliation of the region did not prevent Western scholars from, in a sense, following the Russian lead and treating both eastern and central Europe, including Hungary, Czechoslovakia, Poland, and even the former East Germany as part of the wider "Russian" area. Once again, this could be done with a certain amount of intellectual justification. Despite historical and cultural differences, the countries of east and central Europe were a part of the Soviet 
sphere of influence and of Russia's external empire. While there always remained some room for diversity, especially in the post-Stalin era, and while the more astute scholars of the region never lost sight of the variations that could be found just beneath the surface, the political and economic systems of the central and east European satellite countries were all variations on the Soviet theme, to the extent that it was possible to speak of and to study "Soviet-type" systems. This was particularly the case in the realm of politics and economics, but even in the more hard to tame areas of literary and artistic culture, the restrictions on both form and content common to all communist systems to some degree could allow one to make sense of treating the region, in some respects, as a unit.

To the extent that the primary justification for studying all of these various countries together was their communist systems, the collapse of communism in the region in the late 1980s and early 1990s was bound to play havoc with the very definition of the geographic boundaries of the field. (Indeed, one can make a case that "Communist studies" might have been a better and more accurate label to apply to the intellectual endeavor that more often went under the names of "Russian" or even "Soviet" studies.) With the fall of the Berlin Wall, the domino-like collapse of communist regimes in Eastern Europe, and the subsequent dissolution of the USSR, there could now be, as the title of one text on the region proclaimed, a "return to diversity" in the region (Rothschild, 1989). Less than the widely proclaimed "end of history," the collapse of communism seemed to imply a "return to history" in the region. In this context, Russian/Soviet area studies would need to be geographically redefined.

However, the day of reckoning for the field could be at least temporarily postponed, insofar as the study of "post-communism" would allow for the region to retain its geographic integrity for a bit longer. While the countries of the region were no longer linked by their communist systems, there were all facing similar problems and challenges associated with the legacy of their common communist past. The transition from central planning to the market, the establishment of post-communist political institutions, the resurrection of civil society, the need to clean up after decades of communist era social and environmental decay created a set of issues that, notwithstanding the aspirations of people from Prague to Grozny, continued to bind them to one another at least as much as to the nations of Western Europe or the Islamic world, respectively. 
What Harry Balzer has labeled the "Post-Marxist Space" and what Timothy Colton refers to simply as the "Post-Soviet Zone" could, as Colton has argued, "still be fruitfully studied as a whole, although we will often find ourselves working as hard to explain the variations within the whole as the commonalities" (Steinberg 1999: 3 and 6). Indeed, the 1990s were a decade in which journals, articles, scholarly monographs, textbooks, and both undergraduate and graduate-level courses devoted to post-communist transitions proliferated. The study of such transitions became a cottage industry, as many area specialists turned their attention to examining the processes of change in the region.

But as a long-term proposition, "post-communism" constitutes a tenuous basis on which to continue to organize area studies endeavors. Even in the short-run, such endeavors belie the "area studies" rationale, insofar as their intellectual basis has little to do with "area" in the sense traditionally implied by the term. Instead, the rationale is a process of change which conceivably could extend beyond the "post-Soviet zone" to include China, Vietnam, North Korea and Cuba. Thus, in a sense, "postcommunist studies" might be viewed as something more akin to the economic subfield of "development economics" which cuts across continents, regions, and cultures than to "Russian/Soviet area studies " as traditionally defined.

In the long-term, the study of "post-communism" or the "postSoviet zone" as the basis for keeping the larger Russian/Soviet area studies turf intact is even more problematic, for one cannot remain "post" something or other indefinitely. Though the communist legacy continues to live on in even the cases of the most successful transitions, it is already becoming clear that the "post-Marxist space" is fragmenting. The twenty-seven independent countries of the region (Russia and the other fourteen post-Soviet states, the five post-Yugoslav states, along with the Czech Republic, Slovakia, Hungary, Poland, Romania, Bulgaria, and Albania) manifest this tendency toward fragmentation of the region both in the patterns of their internal development over the 1990s and in the emerging patterns of their foreign relations. At one end of the transition spectrum one finds Poland, Hungary, the Czech republic, Slovenia, and, perhaps, the Baltic states, which are the post-communist states that have moved most quickly in transforming their domestic political and economic systems along the lines of Western-style liberal democracy and 
free-market capitalism. This movement toward the West has, at least for the Poles, Czechs, and Hungarians, been cemented by their accession into the NATO military alliance and by the prospect of future membership in other Western institutions including, most importantly, the European Union. At the other end of the spectrum, the Islamic region of former Soviet Central Asia remains mired in an authoritarian politics which in some cases is barely distinguishable from that of the Soviet era. Somewhere in between are states which include Russia and Ukraine, among others, and which seem stuck in a no-man's land between Sovietstyle communism and the more open societies of the West. While some might continue to argue optimistically that this variation is merely one of the pace of transition, as time goes on it looks more and more like a difference of destination as well.

At least one study of the region has suggested that the very notion that this region is still in the process of transition "requires reappraisal" (Karatnycky 1998). Put somewhat differently, one might suggest that we are approaching the "post post-communist" era, as the main contours and path of development in most post-communist countries are becoming increasingly clear even if the details remain to be worked out in full. One might make a good case that Poland, for example, is irrevocably on a path of westernization even if the timetable of EU accession remains unclear or if some of the legacies of central economic planning remain to be eradicated. What one sees, in effect, might be said to be pretty much what one is likely to get.

Thus, the idea of continuing to include countries as diverse as Hungary, Russia, and Turkmenistan under one area studies roof looks more and more artificial. In some way the boundaries of the area need to be redrawn, but the question is how to do so and on what intellectual basis. The confusion and uncertainty over how to proceed is reflected in the proliferation of labels utilized to redefine former Soviet studies programs, journals, and other endeavors. An examination of the current titles of journals and area studies programs suggests a number of different rationales are being utilized to reorganize former Russian and Soviet area studies:

Politics—-despite the "transitional" feel of labels such as "post-soviet" and "post-communist," they continue to be utilized especially by scholars in the social sciences. A number of scholarly journals, most of 
them renamed and refocused Soviet studies journals, now exist to encourage and publish scholarship in this field. The most prominent of these journals are: Post-Soviet Affairs; Communist and Post-Communist Studies; Journal of Communist Studies and Transition Politics; Transitions. Such politically-based labels, however, are generally not utilized in the titles of college and university area studies programs. One of the few exceptions is Berkeley's program in Soviet and Post-Soviet Studies, though that program exists in addition to rather than in place of that university's Center for Slavic and East European Studies.

Geography - many area studies programs and journals seem, at least in name, to be organized on the basis of geography alone. As was true even before the Soviet collapse, many of the most prominent area studies programs and institutes are called centers of Russian and East European Studies (e.g., Indiana, Michigan, Virginia, Illinois, Kansas). Because that would seem to exclude former Soviet Central Asia and the Caucasus, some programs are identified as centers of Russian, East European, and Eurasian (or Central Asian) Studies (e.g., Georgetown, Wisconsin, Texas, UNCChapel Hill, Iowa). Likewise the journal formerly known as Soviet Studies was renamed, as of 1993, Europe-Asia Studies.

Language-Since its creation in 1948, the American Association for the Advancement of Slavic Studies (AAASS) has been the major U.S. organization promoting area studies in this region. It sponsors a yearly academic conference which is the most widely attended conference focused on the region in the United States, and its journal, Slavic Review, is the central and arguably the most prestigious publication in the field. The "Slavic" designation in its title suggests a cultural/linguistic rationale the goes beyond mere geographic contiguity. A number of prominent university area studies programs also use the term "Slavic" in their names (e.g., Cornell, Ohio State, Berkeley).

The inability to settle on any one of the above approaches reflects more than a disagreement over semantics. Instead, it reflects a more deeply-rooted uncertainty over the scope and mission of the field in the post-communist era. This uncertainty is perhaps best reflected in the utilization of the extremely broad and often poorly defined and incompletely rationalized "Eurasian studies" designation of so many programs. In a good-faith effort to clarify and justify its scope and purpose, the mission statement of one prominent program of Eurasian, Russian, and East 
European studies lays claim to a large turf that stretches "from central Europe to the Pacific and from the Baltic to the Mediterranean, Black and Caspian Seas." The basis for this claim is that this region is "a political and cultural crossroads-borderlands whose histories and futures are inextricably linked to the traditions and trajectories of the rest of Europe, the Middle East, and Asia” (Georgetown University 2000). Yet, while not inaccurate, the "crossroads" rationale still leaves room for doubt as to the logic of including Poland and Azerbaijan, for example, as part of a single area.

Programs that omit the Eurasian (or Central Asian) element from their names seem to recognize this problem, though in fact many such programs with titles such as "Russian and East European Studies " continue to lay a claim to Central Asia and the Caucasus in their mission statements. Even the American Association for the Advancement of Slavic Studies proclaims that it is an organization "dedicated to the advancement of knowledge about Russia, Central Eurasia, and Eastern and Central Europe" (AAASS 2000). The name of the organization notwithstanding, that description seems less guided by the "Slavic" criteria than by, once again, the boundaries of the "post-Soviet zone." Indeed, despite the assortment of labels assigned to the various programs, centers, and journals in the field, the area seems still to be defined largely by the legacy of the communist era.

As the Soviet era recedes into the past, as the trajectories of countries in the region continue to diverge, and as the generations of scholars trained in the Soviet era are eventually replaced entirely by those trained in the 1990s and beyond, the grip of the Soviet legacy on area studies programs will likely recede. New, perhaps multiple, "areas" for area studies programs may be carved out of the "post-Marxist" space. Some will be contained fully within the countries of the former area. Some countries may be "lost" to established programs in Middle Eastern, South Asian, or European studies. Still others may be new programs combining countries from both inside and outside of the former region. Depending on the development of the region itself, the newly-defined boundaries of the various "successor areas" may be marked along linguistic lines, along civilizational/religious lines (a la Huntington), along some newly formed political boundaries, or perhaps via some combination of all of the above. Bureaucratic and institutional considerations 
may also play a role as various academic interests compete to protect and/or expand their scholarly turf.

Evidence of such change is already emerging. Coverage of Central Asia is reported to have increased considerably at the annual meetings of the Middle Eastern Studies Association since the collapse of the USSR (Khalid 1999: 1). The Slavic and East European program at one university has already become a part of a larger European Studies program which is proudly proclaimed by its architects to be the first such pan-European program of its type, including the nations of the EU and the former states of the Soviet bloc, among the leading U.S. research universities (Cornell, 2000). Yet another institution has created a "Central Eurasian studies" program which is again proudly proclaimed by its founders to be the "sole independent degree-granting academic unit in the United States focusing on Central Eurasia" (Indiana 2000). The latter program covers such diverse places as Tibet, Mongolia, former Soviet Central Asia, Hungary, Finland, and Estonia and parts of China.

Yet while scholars and program architects labor over the definition and boundaries of the area, there is a school of thought which, when its logic is taken to the extreme, suggests that all such efforts are misguided, for in the era of globalization, the entire enterprise of area studies may be obsolete. To the extent that globalization is making the borders between states more transparent and porous, and to the extent that such globalizing trends are leading to the homogenization of local cultures, some have argued that it is the various academic disciplines, emphasizing cross-national methods and themes, that offer us the best chance of understanding the world as a whole as well as its various local and regional components.

\section{From Area Studies to the Disciplines: How to Study the Region?}

The basic assumption underlying all area studies programs is that culture matters. Without denying that there are elements of a common humanity which make all human beings alike in certain important respects, the area studies approach nonetheless assumes that there remains a significant proportion of human behavior which is shaped by the specific cultural characteristics and experiences of individual groups found within that larger humanity. One might disagree, of course, as to the spe- 
cific taxonomy of the human species. The boundaries of a culture may be as large as the multinational "civilizations" as spelled out by Huntington or as small as those which merely identify some small minority living within the borders a larger multi-ethnic state. A culture can be arguably as large as "Western civilization" or as small as "the Basque nation." It can include both Poland and Russia within the same cultural boundaries or it can separate them into different sub-groups of human culture, but wherever one chooses to demarcate cultural boundaries, the assumption is that there is something that sets such sub-groups of humanity apart from the rest in significant ways.

Area studies are focused on examining precisely those features of a culture that make it distinct. The favored approach to understanding those distinctive cultural features is what has been termed "thick description" (Fleron 1996: 260). One immerses oneself in all aspects of the culture, and, to a significant degree, the case for study abroad is tied directly to the assumptions and logic of the area studies approach. The true area specialist is familiar with the history, literature, and, of course, the language of the area. Even those interested in contemporary politics or economics can only reach a real understanding of such matters if they are rooted in the essence of the culture as it has emerged over time.

An alternative approach to studying humanity is to focus on those aspects of human behavior that seem constant across cultural boundaries. Much of contemporary social science is, in fact, premised on the assumption that there are universal laws of human behavior that can be said to transcend cultural boundaries. One does not study Russian politics or the French economy (except perhaps in a journalistic fashion in reporting trends and developments), but, instead, one simply studies politics and economics. As one political scientist put it, a central principle of social science is "the elimination of proper names" (Fleron 1996: 264).

The social science discipline that has traveled furthest down this road is economics. Rooted in an understanding of human motivation known as "the rational actor model," mainstream economic theory assumes that all human beings are interest-maximizers who can predictably be expected to act in a manner that allows them to most efficiently pursue their material self-interest. To the extent that there is notable variation in economic behavior across cultural borders, that variation can be explained largely as a consequence of differences in the struc- 
ture of incentives with which individuals are presented.

This view of the universality of economic laws affected much of the approach to economic reform in the post-communist world. Much of the advice for how to reform those economies came not from area specialists armed with specialized knowledge of the region, but from economists in universities and international organizations armed with theoretical knowledge of the laws of economic science. The best-known of those outside economic advisors was the Harvard economist Jeffrey Sachs, who has provided advice to Bolivia, Poland, and Russia. Neither an expert in the history, culture, nor language of any of those countries, Sachs claim to utility was based entirely on his understanding of general concepts and theories of economic development. Many in the post-communist world accepted as much. A former Russian minister of foreign economic relations once criticized those who questioned the wisdom of trying to apply "universal economic laws" to the Russian case without taking cognizance of the special characteristics of the Russian economic situation. He noted that: "There are no special countries from the point of view of economists. If economics is a science, with its own laws-all countries and all economic stabilization plans are the same” (cited in Goldman 1994: 106).

Though economists have traveled furthest down this road toward universality, other social scientists have followed suit. In particular, since the 1950 s many political scientists have sought to mimic the efforts of their colleagues in economics in developing empirical political theory, and in recent years "rational choice models" imported from the economics discipline have become increasingly pervasive in political science. According to one recent count, approximately 40 percent of the articles in the American Political Science Review, the official scholarly journal of the American Political Science Association, were rational choice pieces (Cohn 1999: 26).

Yet, what is most noteworthy is that specialists on the former communist world, and especially specialists on the former Soviet Union, seemed for a long time to buck this disciplinary trend. As long as the Soviet Union existed, Soviet scholars tended to be heavily invested in the area studies approach, emphasizing the uniqueness of the Soviet system. Indeed, the term "Sovietologist" was coined to describe specialists on the former USSR, and its use seemed to imply the existence of a field and subject of study that was quite distinct from the disciplines to which these 
Soviet experts were nominally attached.

The emphasis on the unique qualities of the Soviet system was at the core of the concept of "totalitarianism" which dominated much of the field in the 1950s and 1960s. In asserting the utility of the concept of totalitarianism, Martin Malia (1990: 300) specifically emphasized a view of communism as "something sui generis, a phenomenon qualitatively different from all other forms of despotism in this or previous centuries." Later in the 1960s and 1970s, critics of the totalitarian model, though they did in some cases try to import Western social science concepts such as pluralism, interest groups, and modernization into their analyses, more often than not wound up reasserting a slightly different version of communism as "something sui generis" insofar as they tended to see the Soviet communist system as capable of adaptation in its own unique way to pressures for change and modernization. For example, Jerry Hough, one of the most outspoken critics of the totalitarian model because of what he believed was its inability to account for change in the USSR, nevertheless maintained back in 1979 that "the development of full constitutional democracy in the Soviet Union in the near future is not very great" (1979: 567). Similarly, Samuel Huntington, though not a Sovietologist, captured the belief that the Soviet-type system was capable of meeting the challenges of governance in the late twentieth century on its own terms when he wrote:

The United States, Great Britain, and the Soviet Union have different forms of government, but in all three systems the government governs. Each country is a political community with an overwhelming consensus among the people on the legitimacy of the political system. All three have strong, adaptable, coberent political institutions. (Huntington 1968: 1)

In short, theories of political convergence between East and West were, prior to the $1990 \mathrm{~s}$, much less attractive to mainstream Soviet studies than was the view of communism as an alternative version of modernity. From the perspective of totalitarianism, this alternative form of modernity was genetically defective and behaviorally perverted. From the perspective of critics of the totalitarian school, the communist version of modernity was more an alternative lifestyle which, though not the normative preference of most Sovietologists, was seen as a viable and increas- 
ingly (though not completely) benign form of politico-economic organization. In either case, the underlying assumption was that communism was different enough to be generally excluded from the search for common social, political, and economic patterns that characterized the broader disciplinary-based study of comparative social, political, and economic phenomena.

To be sure, there were periodic calls for an integration of communist studies with the broader study of political, economic, and social theory (Fleron 1969). From time to time there would be concrete results, but for the most part those efforts remained sideshows, with the main stage dominated by studies whose comparative perspective, if it existed at all, stayed within the confines of the communist world (Fleron 1993: especially the introduction and conclusion). Indeed, the preference of Soviet specialists for area studies over disciplinary-based research was, perhaps, best reflected in the fact that specialists on the Soviet economy, nominally located in that most theoretically-oriented discipline of economics, remained as wedded to the area studies orientation as their fellow students of communism from other fields. University-level appointments in "Soviet-type economies" were for the most part an anomaly in a discipline that, much less than political science, provided little room for area studies in general. Yet until recently, such area-oriented economists held tenured positions in a number of prestigious university Economics departments.

The strong area studies orientation of the field of Soviet studies was the result of the mutually-reinforcing effects of a number of factors. The usual argument for area studies rooted in claims of cultural distinctiveness was reinforced by the perceived uniqueness of the communist politicoeconomic model. Thus, political scientists and economists in this case were also attracted by the claims of uniqueness that come more naturally to students of history and culture, narrowly defined. Added to these factors were the extraordinary size and complexity of the USSR along with the lure of well-funded policy-oriented research on America's main Cold War rival and its allies.

With the collapse of Soviet and East-European communist systems, many of the factors propelling the strong area studies orientation of the field began to erode. Post-communist transitions were transforming the differences in political and economic system between the region and the rest of the world from differences of kind to differences of degree (Millar 
1997). This would be a major challenge for an "area" which, as noted previously in this essay, had always been defined as much by the boundaries of the communist politico-economic system as by culture. At the same time, the collapse of the USSR — the last of the world's great multinational empires - also eroded some of the claim to uniqueness of the fifteen successor states. Though Russia remained the world's largest country and one of considerable cultural complexity, its divorce from the rest of the former USSR left it in many ways a more ordinary country than was the historically-anachronistic Soviet Union. Finally, the end of the cold war undermined some of the political motivation that always drove the interest in Soviet area studies, and with that reduction in political motivation came a consequent reduction in funding opportunities for area-oriented research on the region.

It is not only post-Soviet area studies which has been challenged by trends in the 1990s, but area studies in general. The financial impact of the collapse of the USSR and the end of the Soviet threat has, in fact, been broadly felt beyond the region. As one observer has suggested, cutbacks in both government and private support for area studies programs in general are due in large part to "the disappearance of the politically potent rationale for large-scale funding prevailing from the end of World War II to 1989 , viz. that worldwide competition with the Soviet Union required deep knowledge of "foreign" and even "exotic" cultures, histories, terrains, languages, and societies" (Lustick 1997: 175). And while the end of the Cold War was undercutting the political rationale for area studies, the larger phenomenon of globalization seemed to be raising doubts about the intellectual rationale for area studies. The increasingly porous character of national borders and the homogenization of cultures struck directly at the assumption of cultural differentiation that is central to the whole area studies enterprise.

Given the mutually-reinforcing impact of events within the postSoviet region and the larger trend toward globalization, it is not surprising that scholars of the region in the 1990s began to try to build bridges back to their disciplines. In effect, the collapse of the Berlin Wall was causing a crumbling of the walls separating Soviet studies from the rest of academia. By the early 1990s, the call was being sounded for scholars of Russia and other post-communist states to be more explicitly comparative in their approach to studying the processes of political and econom- 
ic change in the region. Scholars of efforts to democratize post-communist states, for example, argued that democratization in the region could be profitably viewed as merely another case of a larger global trend toward democratic government in the late twentieth century (Bova 1991). And not only did former scholars of the region begin to look beyond the postcommunist world for comparable cases, but scholars of other areas and disciplines also began to take a new interest in Russia and Eastern Europe as a place to apply and test concepts and theories.

Meanwhile, a new army of graduate students and young academics was emerging, trained in the new political and intellectual atmosphere of the post-communist era and armed with the conceptual apparatus and methodological tools of their respective disciplines. Applying these concepts and methods to the post-Soviet region, these "Young Turks" were helping to transform the study of the region (Shea 1998). At the same time, the traditional approaches to the region were becoming increasingly passe. This was especially true in economics where, as one well-known economist practitioner of Soviet area studies put it plainly, "Area specialization as we have known it since the mid-1950s is dead as a doornail" (Millar 1997: 6). Even outside of economics, one observer has suggested that "Sovietology may be on the path to becoming an academic slur" (Shea 1998: 16).

But predictably, this move away from area studies toward more comparative, disciplinary-based approaches has stimulated a backlash. Perhaps the most vocal critic of the retreat from area studies has been Stephen Cohen. A well-known scholar of Russian and Soviet politics and history, Cohen (1999: 37) has been critical of what he calls "Russian studies without Russia." He has urged his colleagues (1999: 50) to "stop apologizing for being Russianists" and to "liberate" Russian studies from "comparative political theories that know little or nothing about Russia." Likewise, in the mid-1990s, Slavic Review, the official scholarly journal of the American Association for the Advancement of Slavic Studies (AAASS), provided a forum for a heated debate between those advocating a limited concentration on the traditional geographic turf of the former USSR and post-communist Eastern Europe and those suggesting that Russian and East European experts turn in the direction of cross-area disciplinary based-research. While the former emphasized the limited comparability (i.e., uniqueness) of the post-Soviet region to other parts of the 
world and the need to focus on empirical data collection within the region, the latter argued for the merits of comparison and the need less for data collection than for the development and application of broader analytical frameworks (often disciplinary-based) which would help scholars make sense of the flood of new data pouring out of the region (see especially the exchange between Bunce 1995; Schmitter and Karl 1994; and Karl and Schmitter 1995).

The confrontational, sometimes even hostile tone evident in much of the debate between proponents of the two approaches is arguably, to borrow a phrase from Lenin, an "infantile disorder" of post-Soviet studies. On the one hand, given the long-entrenched dominance of the area studies approach, it is not surprising that the "Young Turks" (along with some of their "old supporters") would feel a need to overstate their case in order best to defend their scholarly revolution. On the other hand, it is predictable that those invested in the area studies approach should feel defensive in the face of the new approaches and methods. This defensiveness may in some cases be a consequence of the threat that the new comparative, disciplinary approaches pose to the turf, funding, and prestige of traditional practitioners of area studies.

But it would be a mistake to reduce the debate entirely to mere questions of self-interest-for there are real and important intellectual principles at stake. The question, as posed by two participants in this debate, is as follows:

Which strategy is better: should the scholars of post-communist tran-
sitions rely primarily on the unique cultural, structural, or behavioral
features inherited from the (...) past in their effort to understand
what the outcomes of these momentous transitions will be? Or, should
they focus on a more generic set of issues and utilize primarily non-
area-specific concepts that presume a less historically constrained range
of choices and hence a greater autonomy for actors? (Karl and
Schmitter 1995: 978)

Though the question, as posed above, seems to require a choice, the fact is that, when the polemical dust finally settles, one is likely to find an emerging consensus that both strategies may be profitably employed. Comparative, cross-area approaches to the study of the countries in the post-Soviet zone are less a replacement for than a complement to area 
studies. Though the tone of the polemics often seems to suggest otherwise, even those most directly engaged in the debate over this issue often wind up conceding as much.

\section{An Enduring Place for Area Studies in Undergraduate Education?}

The 1990s have not been kind to Russian language and Russian area studies programs. The collapse of communism and the elimination of the "Soviet threat" have significantly affected Russian language study-the core of any Russian studies program. The census of pre-college Russian language programs in the United States conducted annually by the Committee on College and Pre-College Russian (CCPCR) suggests that throughout most of the 1990s student enrollments in Russian language courses at the pre-college level have been dropping significantly. For example, the 1993-94 CCPCR census found 292 schools reporting 14,676 Russian language students, while the 1996-97 census found 306 schools reporting only 11,000 students (Committee 1998). These declining enrollments have, in turn, created pressure to eliminate pre-college Russian language programs. By the late 1990s, many teachers were reporting either that their Russian language program was to be eliminated or that their program was under threat (Committee 1998).

Not surprisingly, one finds similar trends at the college level. The early 1990s found reported declines in Russian language enrollments at American colleges and universities to be approaching 50 percent (Innerst, 1995). Teachers of Russian struggle, in many cases, to reach a critical mass in their classes, and international program directors have to beat the bushes to fill the requisite number of spaces in study abroad programs. Once again, pressure to eliminate programs has been a consequence. One observer has noted that some colleges and universities are considering the elimination of Russian language programs and their "replacement" with "modern literature" programs (Hall and Tarro, 1998). In a number of instances, such considerations have become the reality as Russian language and area studies programs have become the victims of financial considerations.

But what makes it easier to succumb to the enrollment challenge and to follow through with such program cuts is precisely the cloud of 
intellectual doubt which hovers over area studies in general and Russian (and/or East European or Eurasian) area studies in particular. Indeed, if it is not only those outside the area studies profession but also those within the field itself who are questioning the borders and logic of one's area or the appropriate balance between area-oriented and cross-area research, it becomes much harder to mount an effective and persuasive defense in the face of the enrollment pressures. Why devote resources to maintaining an area studies program with low enrollments if, in the view of its critics, "area studies is a product of Cold-War security interests; it is merely descriptive; it is parochial and oblivious to changing global forces" (Volkman 1998)? How does one mount a defense of an area studies program if "area-specific forms of knowledge seem archaic constraints on intellectual mobility and global exchange; they belong in a world where nationalists carved boundaries of national territory and images of themselves into the institutions that produce knowledge of the world" (Ludden 1997)? What arguments can be made to counter the perception that "In global discourse, a musty odor accompanies area studies" (Ludden 1997)?

The answer to such questions and criticisms comes in three parts. First, area studies provide much of the knowledge base on which broader, comparative understanding of human phenomena is founded. The acquisition of such a knowledge base is particularly important in American undergraduate education, where one finds so many entering students with a very minimal familiarity with history, literature, or even with the contemporary world. The "descriptive" aspect of area studies that is often criticized is exactly what many contemporary undergraduates need to help fill in this knowledge gap. On that basis, they might go on to develop and pursue interests in broader, comparative studies both at the undergraduate and graduate level. If one assumes that undergraduates start out with knowledge of only one culture and society (their own), then acquisition of similar understanding of at least a second culture and society might be an important stepping-stone to a more universal knowledge of the human condition. If nothing else, such area knowledge provides at least one additional case against which to measure and test more general arguments about the human condition as explained both in scholarship and in the popular media. Put somewhat differently, it is hard to imagine that one might have an understanding of "globalization" if one has 
never studied a culture other than one's own. At best such global knowledge is likely to be superficial.

Second, and related to the above, there exists a tendency among some critics of area studies to try to make the case for cross-national studies by unduly minimizing the significance of culturally specific values and behaviors. In fact, it is not necessarily a contradiction to suggest that a common human nature can coexist with cultural variation. To use a somewhat imperfect analogy, recent reports on the human genome project have suggested that humans and swine might share as much as 80 percent of their DNA in common. With other animals, such as apes, the genetic similarity to humans is even greater. Thus, while biologists have a genetic basis for studying those features of life that humans and other animals share (breathing, the conversion of food into energy, aging, etc.), the 20 percent or less of DNA that differentiates species also provides, to say the least, a very interesting basis for scientific research. Much the same argument can be made about the study of cultural variation within humanity itself. If, for purposes of argument, one assumes that 80 percent of human behavior is constant across cultural boundaries, that would provide a compelling foundation on which to base a search for general laws and patterns of human activity. At the same time, the remaining 20 percent of human values and behavior that are culture bound would provide a basis for the study of human variation that is at least as interesting as the study of what humans share in common. Thus, there is place for area studies right alongside that of disciplinary study and research. Indeed, the ultimate blending of the two approaches might be found in comparative studies of culture which attempt to determine precisely the degrees, trends, causes, and consequences of cultural variation.

Finally, there is a sense in which the recent emphasis on the concept of "globalization" - a concept that sounds very worldly and cosmopolitan-can actually mask a profound parochialism to the extent that it becomes equated with "Americanization." Even Kenneth Prewitt, who as president of the Social Science Research Council in 1996 presided over reforms to the Council that seemed to move in the direction of disciplinary-based research, still maintained that "Globalization does not render the specifics of place inconsequential. Whatever may be meant by the term 'globalization,' the phenomenon to which it points is clearly constructed from dozens to thousands of separate places" (Prewitt 1996). In 
effect, while the worldwide proliferation of McDonald's restaurants is an illustration of globalization, so too are the proliferation of East Asian restaurants in North American cities and the virtual adoption of Indian food as the national cuisine of Great Britain (Friedman 1999: 291-292). Thus, even assuming an increasing homogenization of the globe, a process which is unlikely ever to be complete, an understanding of the resulting globalization may only be completely knowable by tracing its various and diverse cultural roots.

In short, there remains a strong case to be made for area studies and all that it implies about the virtues of language acquisition, cultural familiarity, and immersion in a foreign society. Especially at the undergraduate level where at least a part of one's objective is to increase students' level of empirical knowledge about the world in which they live, a place for area studies and the study abroad programs often attached, alongside that of the disciplines, should be defended. At the same time, the continued health and vitality of area studies programs, including Russian studies, also requires some adjustment in the way area studies programs define their mission and in their relationship to the disciplines themselves.

Area studies programs, first of all, need to be clear in defining the boundaries of their area, and rigorous in explaining the logic of treating that area as a unit of study. Failure to do so will leave area studies programs vulnerable to critics who question their raison d'etre. As previously discussed, this is particularly important for Russian area studies given the centrifugal forces impinging on the post-Marxist space. Particularly as we move further from the communist past, it seems almost inevitable that any newly demarcated area will be smaller than that once covered in Russian and Soviet area studies programs. Given its size and both its historical and potential political and economic importance in the world, Russia itself can probably sustain an undergraduate area studies program, though a good case can be made for continuing to include as a part of such a program an interest in at least some other countries of the post-Soviet region where linguistic and cultural similarities prevail.

At the same time, area studies programs do need to find ways to arm their undergraduates with some of the breadth of vision and conceptual and theoretical tools to help them better understand their region of specialization and its place in the larger global puzzle. That breadth and 
those tools will often come from the various disciplines. For example, it is hard to imagine any student of contemporary Russia would be able to understand the August 1998 financial crisis without at least a basic understanding of international currency markets. Similarly, students of contemporary Russian politics would be well advised to study broader political science concepts such as federalism, majoritarian vs. proportional electoral systems, along with theories and cases of democratization drawn from other parts of the globe. Of course, it is equally the case that a full understanding of current Russian developments requires some understanding of Russia itself_-its culture and its history. Ideally, students of Russia need to be trained in a manner that leaves them both rooted and global. Thus, while the area shrinks in size, the kinds of knowledge which must brought to understanding the area have expanded.

The task, therefore, is a formidable one, but there are at least three different ways in which it can be approached. The first is to more consciously build into area studies courses the kinds of disciplinary based concepts and theories that are most essential for understanding the Russian case. Especially in the social sciences, teachers of Russian-related topics need to retool themselves in disciplinary concepts and theories and pass such knowledge along to their students in area studies programs. But while this can work in disciplines such as political science where area studies and comparative political theory have long coexisted and where courses in Russian politics remain a staple of most political science departments, this approach is less likely to work in the area of economics insofar as the number of economics departments offering undergraduate courses on the Russian economy is much fewer and shrinking.

A second approach is to make more use of cognate courses in the disciplines that are not directly area-oriented. As a graduate student, my decision to minor in Economics and to take general courses in micro and macro-economic theory was viewed by at least one member of the faculty as puzzling insofar as mainstream economic theory did not, in his judgment, seem to be of much relevance to my area interest in the former USSR. Today, it is much less likely that anyone would question the value of such a decision, and some MA programs in Russian studies have begun to build into their curriculum requirements that students acquire at least some disciplinary expertise (Janda 1999; Steinberg 1999). Much the same can be done at the undergraduate level. Of course, the danger here 
is that in loading too many disciplinary-based requirements onto the traditional area studies curriculum one might either dilute the area studies character of the program or limit the opportunities for student experimentation with unrelated courses. As a result, there is a limit to how far one can go in adding disciplinary requirements to the traditional area studies curriculum.

A third approach is a more radical one, involving a move away from area studies as traditionally conceived toward what one might term "global studies." Increasingly popular on college campuses, such programs promise to do a little bit of everything, including, in many cases, both area studies courses along with globally-oriented courses from a number of the traditional disciplines. This approach would seem to provide a reasonable compromise in the globalization v. area studies debate, formally merging, within one program, disciplinary and area-oriented courses. The danger here is superficiality. Lacking a conceptual, theoretical, or methodological core, "global studies" programs run the risk of becoming collections of introductory courses. Moreover, lacking either the conceptual, theoretical, or methodological unity of the disciplines or the cultural unity of area studies programs, the intellectual rationale and mission of "global studies" is often fuzzy. Still, at the undergraduate level, and especially on campuses without the resources to mount full-fledged area studies programs, such "global studies" programs can be a useful introduction for students who want to explore a foreign society or culture in greater depth than possible in the disciplines.

\section{Conclusion: Russian Area Studies and Study Abroad in the 21 st Century}

Paradoxical as it may sound, the phenomenon of globalization can in a sense be seen as undermining the case for undergraduate study abroad, for if the world is truly becoming politically, economically, culturally and even linguistically (with the spread of English as a language of global communication) more homogeneous, then the specifics of place become less important. If there are universal laws of economics, it does not matter much whether one studies them in New York or Moscow. Of course, even in such a globalizing environment, one might still choose to study abroad because of the reputation of a particular university or to 
study with a particular scholar, but the rationale for such foreign study and the manner in which such study would likely be pursued would be much different from the case for foreign immersion associated with area studies programs.

As argued in this essay, however, the phenomenon of globalization does not entirely preempt the need for area studies or for the kinds of foreign immersion programs which are so closely linked to the area studies endeavor, for it is only in the most vulgar caricatures of globalization that the role of place and culture is entirely dismissed. The failures associated with Russia's economic transformation in the 1990s can in large part be attributed precisely to attempts to apply universal economic templates without enough attention to the specifics of the Russian condition. Those failures clearly suggest that a combination of general economic knowledge and location-specific knowledge is required.

Moreover, the transformation and ferment that have characterized Russia over the past decade would seem to make it an exciting place for students to study abroad. Yet, for a variety of reasons, students are sometimes reluctant to do so. Their sense of Russia as a country in perpetual crisis, and the personal hardships and safety concerns that students, with at least some justification, see as the result, can act as deterrents. The attitude and temperament required to commit to a year in Moscow or St. Petersburg, never mind other, more isolated locales within Russia or the post-communist world, are a bit different than what is required to spend a year in Paris or Rome.

Yet the reasons for overcoming inhibitions are perhaps stronger than ever. Not only is study in Russia an opportunity to utilize and hone one's language skills and to immerse oneself in the local culture, but it is also an opportunity to be at the center of a laboratory of political, social, economic, and cultural change. Moreover, the opportunities for foreign students in Russia are greater than ever. Travel within Russia, once highly restricted, is now much more open. Student internships, virtually impossible in the Soviet era, provide yet another opportunity to experience the country more fully than ever before. Entire subjects of study, largely taboo in Soviet times, can now be openly examined. So while study abroad in Russia once centered largely on politically safe areas such as advanced language training and Russian literary classics, students can now add to that list the study of political and economic performance and transformation, 
social issues such as poverty, the environment, or women's rights, and even controversial historical topics such as the Stalin era purges.

In order to appeal to a larger pool of students, study abroad organizers need to make a concerted effort to take advantage of the opportunities that the new Russia has to offer. Thus, for the area studies major with an interest in the Russian economy (or even for the economics major willing to study a little Russian language), courses or programs in Russia (or other post-Soviet states) focusing on issues of economic transformation need to be made available along with internships in private sector companies in Russia. For the student of Russian democratization, courses, programs, and internships related to that theme should also be developed. To be sure, there are still obstacles that will make such efforts difficult in many cases, but unlike in the Soviet era, it is no longer beyond the realm of possibility.

The academic preparation required to make the most of a study abroad opportunity in Russia remains, in part, unchanged from what it was during the Soviet era. Despite the significant globalization of English as a second language, at least a basic knowledge of Russian is still essential, with "the more the better" being the prevailing rule. Likewise, prior study of Russian culture and history is also important to help put contemporary Russia into perspective. At the same time, the recognition by many scholars that Russia can no longer be understood in isolation from larger world events and trends or from the concepts and theories developed by scholars to help make sense of that larger world also applies to student preparation. Indeed, precisely because Russia is in such a state of flux and the source of so much new (and often conflicting) information and reportage, scholars and students alike need organizing frameworks to help them make sense of things and to see the forest from the trees. In the process, students of Russia can use that area-specific knowledge to test the realism of those larger theories and conceptual frames.

In short, for the student, for the scholar, and for the study abroad coordinator, the challenge is to blend the best of what area studies and disciplinary knowledge have to offer. The challenge is a formidable one, and there is unlikely to be any one model or any prescribed set of courses. Yet, if the challenge is real, so is the opportunity. The debate within Russian area studies about the scope and nature of the field is a healthy one, prompted by the collapse of communism, but in many ways long overdue. 


\section{References}

AAASS Website. Online http://www.fas.harvard.edu/ aaass/about.htm. Accessed June 28, 2000.

Barber, Benjamin. Jibad vs. McWorld. New York: Random House. 1995. Bova, Russell. "Political dynamics of the post-communist transition: a comparative perspective." World Politics. 44:1, 113-138. 1991.

Bunce, Valerie. "Should transitologists be grounded?" Slavic Review. 54:1, 112-127. 1995.

Bunce, Valerie. "Paper curtains and paper tigers." Slavic Review. 54:4, 979-987. 1995.

Cohen, Stephen F. "Russian studies without Russia." Post-Soviet Affairs. 15:1, 37-55. 1999 .

Cohn, Jonathan. "Irrational exuberance: when did political science forget about politics?" The New Republic. October 25, 1999, 25-31. 1999.

Committee on College and Pre-College Russian. Fall '98 census article. Online: american.edu/research/CCPCR/article.htm. Accessed July $17,2000$.

Cornell University. Institute for European Studies. 2000. Online: .einaudi.cornell.edu/Europe/right.html. Accessed June 29, 2000.

Fleron, Frederic J. Communist Studies and the Social Sciences. Chicago: Rand McNally. 1969.

Fleron, Frederic J. and Hoffmann. Post-Communist Studies and Political Science. Boulder, CO: Westview Press. 1993.

Fleron, Frederic J. "The logic of inquiry in post-Soviet studies: art or science." Communist and Post-Communist Studies. 29:3, 245-274. 1996.

Friedman, Thomas L. The Lexus and the Olive Tree. New York: Farrar, Straus, and Giroux. 1999.

Georgetown University. Center for Eurasian, Russian, and East European Studies webpage. 2000. www.Georgetown.edu/sfs/ceres/index.html. Accessed June 28, 2000.

Goldman, Marshall I. Lost Opportunity: Why Economic Reforms in Russia Have Not Worked. New York: W.W. Norton. 1994.

Hall, Peter A. and Tarrow, Sidney. "Globalization and area studies: when is too broad too narrow?" The Chronicle of Higher Education. January 23, 1998. Online: http://chronicle.com/data/articles...t-44.dir/issue20.dir/20b00401.htm. Accessed July 17, 2000.

Hough, Jerry, and Fainsod, Merle. How the Soviet Union Is Governed. 
Cambridge, MA. and London: Harvard University Press. 1979.

Huntington, Samuel P. Political Order in Changing Societies. New Haven and London: Yale University Press. 1968.

Huntington, Samuel P. The Clash of Civilizations and the Remaking of World Order. New York: Simon and Schuster. 1996.

Indiana University. Department of Central Eurasian Studies. 2000. Online: www.indiana.edu/ ceus/main.htm. Accessed June 28, 2000. Innerst, Carol. "Russian language's fall from favor causes worry." Washington Times. October 12, $1995 . \quad$ Online: http://www.inform.umd.edu:8080/EdRes/Colleges/ARHU/Depts/He brewEastAsian/area/html. Accessed July 17, 2000.

Janda, Laura A. "Reforming the area studies curriculum: defining issues and objectives." Newsnet: The Newsletter of the AAASS. 39:2, 1-4.

Karatnycky, Adrian. "Nations in transit: from change to permanence." Nations in Transit. ed. Karatnycky et al. Freedom House. 1998 Online: freedomhouse.org/nit98/karat.html. Accessed July 26, 2000.

Karl, Terry Lynn and Schmitter, Philippe C. "From an iron curtain to a paper curtain: grounding transitologists or students of postcommunism?" Slavic Review. 54:4, 965-978. 1995.

Khalid, Adeeb. "Your asia or mine: central asian studies in post-soviet times." Newsnet: The Newsletter of the AAASS. 39:5, 1-3. 1999.

Kundera, Milan. "The Tragedy of Central Europe." New York Review of Books. XXXI:7, 33-38. 1984.

Ludden, David. "The territoriality of knowledge and the history of area studies.” 1997. Online: www.ses.upenn.edu/ dludden/areast1.htm. Accessed July 17, 2000.

Lustick, Ian S. "The disciplines of political science: studying the culture of rational choice as a case in point." PS: Political Science and Politics. XXX:2, 175-179. 1997.

Malia, Martin (“Z”). “To the Stalin mausoleum.” Daedalus. 119:1. 1990.

Millar, James R. "Doom without gloom: area studies and the economics profession." Newsnet: The Newsletter of the AAASS. 37:4, 5-6. 1997.

Prewitt, Kenneth. Presidential items. Social science research council web page. 1996. Online: http://www.ssrc.org/mitems6.htm. Accessed July $17,2000$.

Rosenau, James N. Turbulence in World Politics: A Theory of Change and Continuity. Princeton: Princeton University Press. 1990. 
Rothschild, Joseph. Return to Diversity: A Political History of East Central Europe Since World War II. New York and Oxford: Oxford University Press. 1989.

Schmitter, Philippe C. and Karl, Terry Lynn. "The conceptual travels of transitologists and consolidologists: how far to the east should they attempt to go?" Slavic Review. 53:1, 183-185. 1994.

Shea, Christopher. "New faces and new methodologies invigorate Russian studies." The Chronicle of Higher Education. February 20, 1998, A16A18. 1998.

Steinberg, Mark D., Balzer, Harley, and Colton, Timothy J. "Reforming the area studies curriculum: three views." Newsnet: The Newsletter of the AAASS. 39:4, 1-6. 1999.

Volkman, Toby Alice. "Crossing borders." Ford Foundation Report. Winter. 1998. Online: www.fordfound.org/publications. Accessed July $17,2000$.

\section{Suggested Readings:}

\section{On Developments in Russia and the Post-Communist States}

Brady, Rose. Kapitalizm: Russia's Struggle to Free It's Economy. New Haven and London: Yale University Press. 1999.

Brown, J.F. Hopes and Shadows: Eastern Europe after Communism. Durham, NC: Duke University Press. 1994.

Gustafson, Thane. Capitalism Russian-Style. Cambridge, England and New York: Cambridge University Press. 1999.

Karatnycky, Adrian, et. al. Nations in Transit, 1998 : Civil Society, Democracy, and Markets in East Central Europe and the Newly Independent States. New Brunswick, USA: Transaction. 1999.

Remnick, David. Resurrection: The Struggle for a New Russia. New York: Vintage Books. 1998.

Rosenberg, Tina. The Haunted Land: Facing Europe's Ghosts After Communism. New York: Vintage Books. 1996.

Shevtsova, Lilia. Yeltsin's Russia: Myths and Reality. Washington, D.C.: Carnegie Endowment for International Peace. 1999.

Smith, Gordon B. State Building in Russia: The Yeltsin Legacy and the Challenge of the Future. Armonk, NY and London: M.E. Sharpe. 1999. 
On Trends \& Debates in Russian Area Studies:

Bova, Russell. "Political dynamics of the post-communist transition: a comparative perspective." World Politics. 44:1, 113-138. 1991.

Bunce, Valerie. "Should transitologists be grounded?" Slavic Review. 54:1, 112-127. 1995.

Bunce, Valerie. "Paper curtains and paper tigers." Slavic Review. 54:4, 979-987. 1995.

Cohen, Stephen F. "Russian studies without Russia." Post-Soviet Affairs. 15:1, 37-55. 1999.

Fleron, Frederic J. and Hoffmann. Post-Communist Studies and Political Science. Boulder, CO: Westview Press. 1993.

Fleron, Frederic J. "The logic of inquiry in post-Soviet studies: art or science." Communist and Post-Communist Studies. 29:3, 245-274. 1996.

Karl, Terry Lynn and Schmitter, Philippe C. "From an iron curtain to a paper curtain: grounding transitologists or students of postcommunism?" Slavic Review. 54:4, 965-978. 1995.

Schmitter, Philippe C. and Karl, Terry Lynn. "The conceptual travels of transitologists and consolidologists: how far to the east should they attempt to go?" Slavic Review. 53:1, 183-185. 1994. 